\title{
DUAL EPISODES OF HERPES ZOSTER IN A SINGLE YEAR IN IMMUNOCOMPETENT MALE CASE REPORT
}

Gaurav Murti1 1 , Anil Kumar Gupta², Sumi Saxena ${ }^{3}$

\section{HOW TO CITE THIS ARTICLE:}

Gaurav Murti, Anil Kumar Gupta, Sumi Saxena. "Dual Episodes of Herpes Zoster in a Single Year in Immunocompetent Male Case Report". Journal of Evolution of Medical and Dental Sciences 2014; Vol. 3, Issue 71, December 18; Page: 15187-15189, DOI: $10.14260 /$ jemds/2014/4041

ABSTRACT: Herpes zoster, is a viral disease characterised by painful skin rash with blister in a limited area on one side of body. Varicella zoster virus ${ }^{1}$ is the cause of both varicella (Chicken pox) and zoster (Shingles).It initially causes chicken pox and then remains latent for decades in cranial nerve, dorsal root and autonomic nervous system ganglia. ${ }^{2}$ Three genotypes of this alpha herpesvirus have been identified and shown to have geographical variations. ${ }^{3}$ The virus gets reactivated after a variable period of time to cause zoster. Recurrences of zoster ${ }^{4}$ are common in immune-compromised patients, those having lymphoma, hiv, diabeties or on immune-supressive drugs especially the more profound suppression required for bone marrow transplantation.5,6 However recurrences are rare in immune-competent individuals. We report here a case of recurrent herpes zoster in a immune-competent male within 1 year of the first attack of herpes zoster.

KEYWORDS: Herpes, varicella, Immunocompetent.

INTRODUCTION: Herpes zoster commonly known as shingles is a viral disease, characterized by unilateral, dermatomal pain, and rash that results from reactivation and multiplication of endogenous varicella zoster virus that had persisted in latent form with in sensory ganglia following an earlier attack of varicella. ${ }^{7}$ It is uncommon in childhood and the incidence increases with age. It affects both sexes equally.

CASE REPORT: 20 yr male presented with 3 days history of painful, grouped vesicular eruption over left C2-C3 dermatome. On examination besides the vesicular eruptions patient was also having scar marks over right $\mathrm{C} 2-\mathrm{C} 3, \mathrm{~V} 3$ dermatome. Complete history was taken, patient had similar painful vesicular eruptions one year back.

INVESTIGATIONS: systemic examination was normal. Routine investigations were normal. HIV and HBS antigen status of the patient was negative. Patient was not on immune supressants. Liver function tests and kidney function tests were under normal limits. 

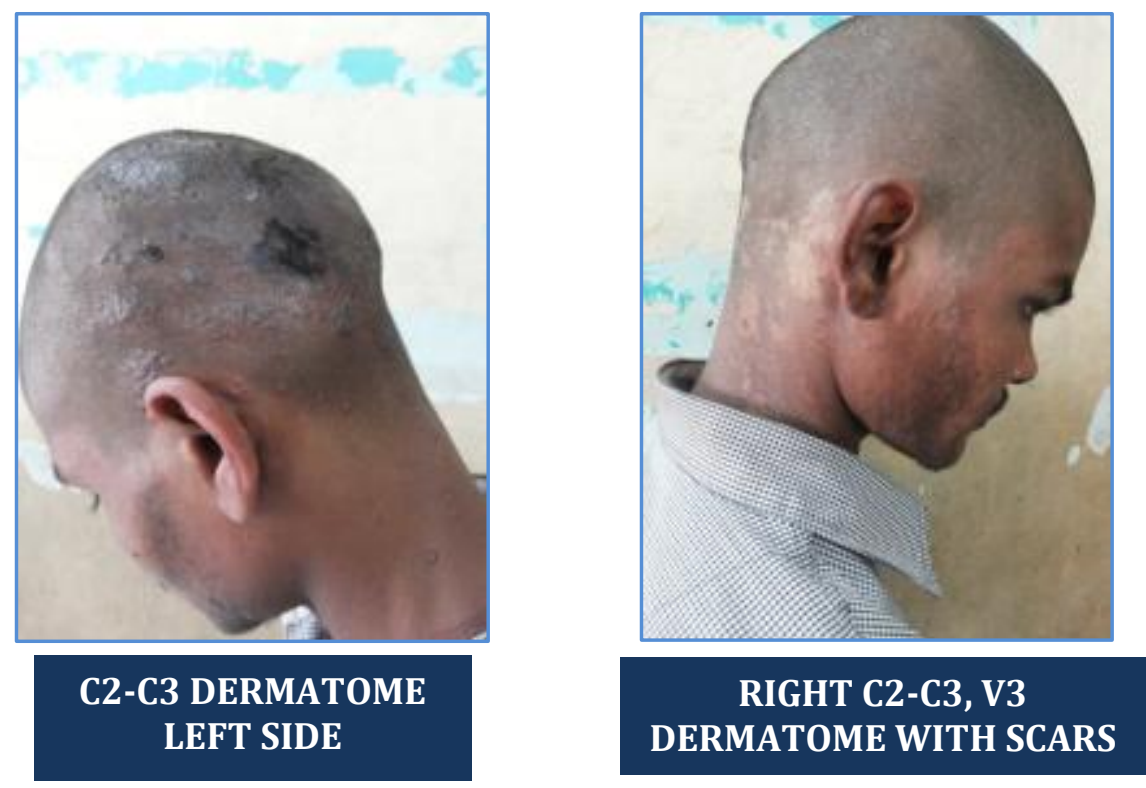

DISCUSSION: Varicella (chicken pox) and herpes zoster (shingles) are distinct clinical entities caused by a single member of the herpesvirus family, varicella zoster virus (VZV). ${ }^{1}$ It is a neurotropic virus which initially causes chicken pox and then remains latent for decades and causes zoster after reactivation. Cell mediated immunity (CMI) is more important in protection against and control of the infection and reactivation of latent virus. In patients with impaired immunity, both the incidence and severity of zoster are increased, and it is frequently complicated by disseminated cutaneous disease and systemic involvement. This is seen in malignancy, especially lymphomas. Repeated and disseminated zoster eruptions are frequently detected in immune-compromised patients especially those with impaired cellular immunity. ${ }^{4}$ People at risk are those having malignancy especially lymphoma, those on cytotoxic or immunosuppressive therapy5,6 \& those infected with Human Immuno-deficiency Virus. On the other hand, second attacks of herpes zoster in immune-competent individuals, although described, are rare. The observation that most persons develop zoster only once, if at all, suggests that one episode of zoster may enhance immune response to the levels that are sufficient to prevent recurrences. The exact mechanism of recurrent herpes zoster in immune competent individuals is not known and general \& Varicella Zoster specific immune investigations are unlikely to indicate a reason. ${ }^{8}$ Blocking of cell mediated defenses by rising levels of specific antibodies after exposure to exogenous Varicella Zoster virus or by some other mechanism may be a possibility. Recurrent zoster may develop on the site of previous eruption or at a different site. The interval between first eruption and the recurrence may vary from 2 weeks to 25 yrs. Relapses should be treated with systemic acyclovir. However early relapses following shortly after the first attack of herpes zoster treated with acyclovir should be considered as a manifestation of immunity disorder and such cases are treated with other anti-viral drugs. ${ }^{2}$

TREATMENT: patient was given oral acyclovir 800mg 5 times daily for 07 days.patient recovered completely. 


\section{REFERENCES:}

1. Heininger U, Seward JF. Varicella. Lancet 2006; 368; 1365-76.

2. Cohrs RJ, Gilden DH, Mahalingam R. Varicella zoster virus latency, neurological disease and experimental models: an update. Front Biosci 2004; 9: 751-62.

3. Loparev VN, Gonzalez A, Deleon-Carnes M et al. Global identification of three major genotypes of varicella-zoster virus: Longitudinal clustering and strategies for genotyping. J Virol 2004; 78: 8349-58.

4. Cerny Z. [Recurrent eruptions of herpes zoster] [Article in Czech]. Bratisl Lek Listy 1999; 100 (9): 515-8.

5. Schuchter LM, Wingard JR, Piantadosi Set al. Herpes zoster infection after autologus bone marrow transplantation.Blood 1989; 74: 1424-7.

6. Koc Y, Miller KB, Schenkein DP et al. Varicella zoster virus infection following allogenic bone marrow transplantation: Frequency, risk factors, and clinical outcome. Biol blood marrow transpl 2000; 6: 44-9.

7. Fitzpatricks textbook of dermatology.

8. Junker AK, Angus E, Thomas EE. Recurrent Varicella-Zoster Virus infections in apparently immune competent children. Paediatric Infect Dis J 1991; 10 (8): 569 -75.

\section{AUTHORS:}

1. Gaurav Murti

2. Anil Kumar Gupta

3. Sumi Saxena

\section{PARTICULARS OF CONTRIBUTORS:}

1. $3^{\text {rd }}$ Year Junior Resident, Department of Dermatology, B. R. D. Medical College, Gorakhpur.

2. Assistant Professor, Department of Dermatology, B. R. D. Medical College, Gorakhpur.
3. Senior Resident, Department of Anaesthesia, B. R. D. Medical College, Gorakhpur.

\section{NAME ADDRESS EMAIL ID OF THE CORRESPONDING AUTHOR:}

Dr. Gaurav Murti, Type 3, D. C. M, 21, B. R. D. M. C., Gorakhpur-273013.

Email: garvmurti@gmail.com

Date of Submission: 28/11/2014.

Date of Peer Review: 29/11/2014.

Date of Acceptance: 13/12/2014.

Date of Publishing: 18/12/2014. 